\title{
Determinants of Strategic Sourcing and the impact of them on Fast Moving Consumer Goods Industry in Sri Lanka
}

\author{
T.H.T.D. Perera, P.W.G. Madhushani, D. G. N. D. Jayarathna
}

\begin{abstract}
Sourcing function has become a crucial activity in any organization from recent decades because total supply chain effectiveness of any organization is achieved mainly through efficient sourcing function. Therefore, the study aimed to findout the determinants affecting on strategic sourcing and the impact of each determinant. The study population was targeted to those who are engaged in sourcing of five top ranked players in the Fast-Moving Consumer Goods (FMCG) industry in Sri Lanka. A sample of 300 respondents were considered under stratified sampling method. Through a factor analysis, five factors have been identified as the determinants of strategic sourcing. The identified factors are, supplier's reliability and Quality, supplier's Business Environment, supplier's sustainability, cost advantage and Customer Responsiveness. A linear regression analysis was undertaken to distinguish the impact of each identified determinant on strategic sourcing.
\end{abstract}

Key words: Strategic sourcing, Supply Chain Effectiveness, Fast Moving Consumer Goods Industry

\section{I.INTRODUCTION}

Strategic sourcing can be considered as a collection of science, art and heavy data analytics with the use of a wideranging methodology designed to discover all viable possibilities in pursuit of total cost saving while overall quality or service equivalence or improvement. (David \& Fred, 2001). The function of sourcing in Supply Chain Management (SCM) has gained a great attention in recent decades. In traditional sourcing, the typical chant is 'get three bids and proceed with the lowest' while strategic sourcing in simply engages with qualified suppliers and engages in a long-term bond with maximum effort.

Strategic sourcing enhances the efficiency and lot of benefits are being achieved through this. but to realize these advantages, it is critical in nature to select and maintain competent suppliers. In any organization today relates to sourcing of materials (Raw materials-RM, packing materials-PM) and services required to transform raw material into finished products to make it ready for the final

\section{T.H.T.D. Perera1,}

1JAT Holdings (Pvt) Ltd, No.351, Pannipitiya Road, Thalawathugoda;

P.W.G. Madhushani2,

2Department of Logistics and Transportation, Faculty of Management, Humanities and Social Sciences, Colombo International Nautical and Engineering College (CINEC Campus), Malabe, Sri Lanka;

D. G. N. D. Jayarathna3

3Department of Logistics and Transportation, Faculty of Management, Humanities and Social Sciences, Colombo International Nautical and Engineering College (CINEC Campus), Malabe, Sri Lanka; consumption. Strategic sourcing consists of processes of planning, evaluating, implementing and controlling all sourcing activities undertaken by an organization to achieve its long-term goals (Amy, 2003). Since FMCG industry encountered to speedy changes, it is important to identify how successfully implement strategic sourcing to a specific company based on the knowledge of their most vital goods and services and decide how crucial they are to day-to-day operations in SCM. Generally, it is considered as the cornerstone of the SCM which can be considered as the foundation of developing channels of supply at the lower total cost, but with required quality standards.

The transformation from traditional purchasing methods to a strategic sourcing, requires three principal philosophies that drive the strategic elements which can be noted as;

- emphasis on the total delivered value but not the purchase price

- collaborative approach when dealing with suppliers, rather than oversight.

- emphasis on enhancing profitability and supply chain performance, rather than cost savings. (Parniangtong, 2016)

The transformation from purchasing to strategic sourcing led to the development of FMCG market reaching vast changes during the last decade. Thus, subjected study focuses on determinants of strategic sourcing to enhance the supply chain process in FMCG industry in Sri Lanka.

\section{A. Research Problem and objectives}

Su (2013) has mentioned that, in FMCG industry responsible persons should understand the fact that strategic sourcing significantly contributes to expand the business reach. Today, with the competitive environment and future challenges, companies are seeking identify what kind of favourable changes can be generated and simply why do companies need to move from traditional sourcing to strategic sourcing. Therefore, research objectives have been generated to find out answers for the above issue.

Objective 01:

1tharukaperera1994@gmail.com,

2gangam@cinec.edu

3nuwan@cinec.eduWhat are the determinants of strategic sourcing in FMCG industry?

Objective 02:

What is the impact of each determinant on strategic sourcing?

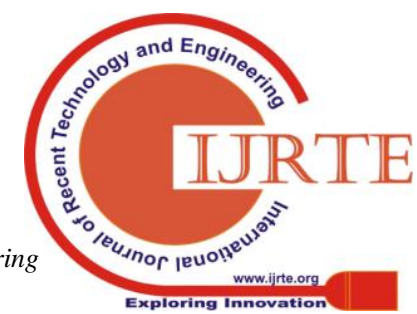




\section{B. Significance of the research}

The study is scientifically significant since this area of study has not been given an intensive focus with related to the field of strategic sourcing in FMCG industry in Sri Lanka. There exists a lack of researches conducted for the strategic sourcing process in supply chain management. Because the lack of knowledge in this arena, it makes gaps between theories of sourcing strategies \& practices. In FMCG industry of Sri Lanka, total sourcing process is labor intensive which lead towards decision making errors mainly due to biasness and many other reasons which will create adverse results to overall supply chain process. Therefore, this study will cover the possibilities where those labors can identify key areas to enhance the processes. Further, the giant players in Sri Lankan FMCG industry do not tend to evaluate each and every supplier even once in year. Practice of selecting a supplier within a very short time period when there is a requirement has led to have critical issues. Accordingly, overall significance is that, this thesis will identify the key success factors influenced in strategic sourcing which will directly impact the overall supply chain performance in firms who play in FMCG industry in Sri Lanka.

\section{Literature review}

Strategic sourcing can be considered as a collection of science, art and heavy data analytics with the use of a wideranging methodology designed to discover all viable possibilities in pursuit of total cost saving while overall quality or service equivalence or improvement. (David \& Fred, 2001). Based on the empirical studies of Monczka (2009), Kraljic (1983), Adipola (2017), Carr \& Smeltzer (1999), Benn (2009), Reck \& Long (1988), Ruth (2012), Harps (2000), Adegoke \& Arnold (2009), Wang \& Che (2007), Amy (2003), Stanley (2012), following factors have been indetified as the determinets of Strategic souricng.

\section{Independent Variables}

1. Cost of Sourcing cost of transportation

2. Price Competitiveness

3. Payment term given by the supplier

4. Technical Capability of the supplier

5. Quality Assessment of the product

6. Commercial support in NPDs/EPDs

7. Ethical Contract

8. BCP (Business Continuity Plan of the supplier)

9. Financial health of the supplier

10. Organizational Profile of the supplier

11. Deliveries on-time

12. Lead Time

13. Ease of Communication with the supplier

14. Response of Customers

15. Performance History of the supplier in the respective industry

16. Risk Factors

17. Political stability of the supplier

\section{METHODOLOGY AND EXPERIMENTAL DESIGN}

The research design falls in to the category of casual research where the main objective is to verify the extent and nature of cause-and-effect relationship between variables.
Accordingly, the dependent variable of the paper is "strategic sourcing" and the determinants of strategic sourcing are considered as the independent variables. A Questionnaire was prepared with 03 sections to collect the primary data required for the study along with 17 factors which were recognized as the driving forces affecting to strategic sourcing in FMCG industry in Sri Lanka.

\section{A. Primary Survey}

According to the data identified by observation, there are around 65 recognized FMCG players in Sri Lanka where multinationals' contribution is around $75 \%$ while local players' contribution is only around $25 \%$. Based on that, the employees who are engaged in sourcing in FMCG industry in Sri Lanka have taken as the target population of this study. Five giant players among 65 recognized FMCG players, were considered as the sample covering more than $50 \%$ of the FMCG market and they are Unilevers, Fonterra, Nestle, Hemas and Reckitt Benckiser.

A well-structured Questionnaire based on 5-point Likert scale was distributed using stratified random sampling technique considering the product portfolio of each organization.

\section{A. Model Development \\ 1) Validity and Reliability:}

The reliability or the internal consistency of the collected primary data was checked by using the Cronbach's Alpha which is commonly used to verify the reliability of the scale in a multiple Likert-Scale questionnaire. Coefficient is required to be 0.7 or higher value to be reliable. Cronbach's Alpha can be calculated using the following equation. Taber, K. (2017).

$$
\propto_{s}=\frac{m_{w}\left(\sum_{s} \lambda_{s^{\frac{1}{2}}}-1\right)}{\left(\sum_{s} \lambda_{s^{\frac{1}{2}}}\left(m_{w^{-1}}\right)\right)} \ldots \ldots \ldots \ldots \ldots \ldots \ldots \ldots \ldots \ldots \ldots \ldots \ldots \ldots
$$

\section{2) Data Analytical Method:}

Software has been used to analyse the gathered data which is called as SPSS 16.0 (Statistical Packages for Social Sciences). A descriptive analysis has been conducted to identify the relationship of the explanatory variables and the response variable.

\section{3) Factor Analysis:}

This is a statistical instrument, used to find factors among observed variables.

This can be divided in to two categories, factor analysis and confirmatory factor analysis. (Taber, K. 2017). In this study the exploratory factor analysis method is used to analyse data.

To make the data set accepted KMO value should be greater than 0.5 but the value of Bartlett's test should be greater than 0.7 in order be the test significant. KMO measure the sampling adequacy of the research. KMO index can be computed as follow. 


$$
\mathrm{KMO}=\frac{\sum_{\mathrm{i}} \sum_{\mathrm{j} \neq \mathrm{i}} \mathrm{r}_{\mathrm{ij}}^{2}}{\sum_{\mathrm{i}} \sum_{\mathrm{j} \neq \mathrm{i}} \mathrm{r}_{\mathrm{ij}}^{2}+\sum_{\mathrm{i}} \sum_{\mathrm{j} \neq \mathrm{i}} \mathrm{a}_{\mathrm{ij}}^{2}}
$$

Communalities are the proportion of variance accounted for the common factors of a variable. Communalities scores range from 0 to 1 . Value of 1 means that common factors will explain all variables and a value of 0 means that common factors are not explaining all variables.

Initial solution table explained the total variance. Eigenvalue is the total variance described by each factor. Eigenvalues that is less than one does not have enough total variance explained to represent a unique factor.

\section{Regression Analysis}

Effect, impact or influence of variables is analysed by using regression analysis. If there is one independent variable, it is considered to be a simple regression model. If there are more than one independent variable, that is multiple regression model. As a linear model, we apply Classical Linear Regression model (CLRM). This is called Ordinary Least Square (OLS) model. Further this is called "Gaussian Model”. (Gujarati, N. 1978)

\section{III.DATA ANALYSIS AND THE RESULTS \\ A. Reliability}

If the value of Cronbach's alpha is higher than 0.6 or 0.7 , data are in an acceptable level.

Table 1.2 Reliability for Full Data Set

\begin{tabular}{|r|r|}
\hline Cronbach's Alpha & N of Items \\
\hline .712 & 17 \\
\hline
\end{tabular}

Source: Research data

According to the table the value of Cronbach alpha which in this study is 0.712 and reflects in the acceptance region of the measuring instrument. It indicates the presence of internal consistency with respect to the precise sample.

Table 1.1 Kaiser-Meyer-Olkin (KMO) and Bartlett's Test

\begin{tabular}{|ll|l|}
\hline $\begin{array}{l}\text { Kaiser-Meyer-Olkin Measure of Sampling } \\
\text { Adequacy. }\end{array}$ & .785 \\
Bartlett's Test of Sphericity & Approx. Chi- & $2.740 \mathrm{E} 3$ \\
& Square & \\
& Df & 153 \\
& Sig. & .000 \\
\hline
\end{tabular}

Source: Research data

The relationship of each variable as well as the strength among the variables is measured using Kaiser-Meyer-Olkin (KMO) and Bartlett's test. Sample adequacy will be measured by KMO test. In this test KMO test statistic value is 0.785 which is greater than 0.6 , concluding that sample is adequate in this study. With reference to the given test statistic value and as it is more than 0.6.

And also in table 1.1, sig - value of the Bartlett's test is 0.000 , by indicating that there is a high strength in relationships.

\section{B. Communalities}

Communalities mention the amount of variance in each variable that is accounted for. Variables which fit well with factor solutions are determined by higher extraction values (more than 0.6) while small values should possibly be dropped from the analysis since they are considered as not fitted.

According to the below table 1.3, All the variables except price competitiveness, organizational profile of the supplier, Performance history of the supplier in the respective industry are having extraction values greater than 0.6. Hence those variables are considered as fitted very well with the analysis. Majority of the respondents over $86 \%$ of variance in Ethical contract is explained by the extracted components and the least is $43.5 \%$ of variance in Price competitiveness is explained by extracted component.

According to table 1.4, the Eigen values that are less than one will be removed from the analysis, as they don't have enough strength to denote a unique factor

Table 1.3 Communalities

\begin{tabular}{|c|c|c|}
\hline & Initial & Extraction \\
\hline Cost of Sourcing & 1.000 & .685 \\
\hline Price Competitiveness & 1.000 & .435 \\
\hline Payment term given by the supplier & 1.000 & .714 \\
\hline $\begin{array}{l}\text { Technical Capability of the } \\
\text { supplier }\end{array}$ & 1.000 & .741 \\
\hline Quality Assessment of the product & 1.000 & .721 \\
\hline $\begin{array}{l}\text { Commercial } \quad \text { support } \quad \text { in } \\
\text { NPDs/EPDs }\end{array}$ & 1.000 & 639 \\
\hline Ethical Contract & 1.000 & .868 \\
\hline $\begin{array}{l}\text { BCP (Business Continuity Plan of } \\
\text { the supplier) }\end{array}$ & 1.000 & .836 \\
\hline Financial health of the supplier & 1.000 & .691 \\
\hline $\begin{array}{l}\text { Organizational Profile of the } \\
\text { supplier }\end{array}$ & 1.000 & .471 \\
\hline Deliveries on-time & 1.000 & .747 \\
\hline Lead Time & 1.000 & .629 \\
\hline $\begin{array}{l}\text { Ease of Communication with the } \\
\text { supplier }\end{array}$ & 1.000 & .824 \\
\hline Response of Customers & 1.000 & .746 \\
\hline $\begin{array}{l}\text { Performance History of the } \\
\text { supplier in the respective industry }\end{array}$ & 1.000 & .558 \\
\hline Risk Factors & 1.000 & .744 \\
\hline Political stability of the supplier & 1.000 & .646 \\
\hline
\end{tabular}

Extraction Method: Principal Component Analysis. Source: Research data

Table 1.4 Total variance explained 


\begin{tabular}{|c|c|c|c|c|c|c|c|c|c|}
\hline \multirow[b]{2}{*}{$\begin{array}{l}\text { Con } \\
\text { pon } \\
\text { nt }\end{array}$} & \multicolumn{3}{|c|}{ Initial Eigenvalues } & \multicolumn{3}{|c|}{$\begin{array}{l}\text { Extraction Sums of } \\
\text { Squared Loadings }\end{array}$} & \multicolumn{3}{|c|}{$\begin{array}{l}\text { Rotation Sums of Squared } \\
\text { Loadings }\end{array}$} \\
\hline & Total & $\begin{array}{c}\% \text { of } \\
\text { Varianc } \\
\text { e }\end{array}$ & $\begin{array}{c}\text { Cumulati } \\
\text { ve } \%\end{array}$ & Total & $\begin{array}{c}\% \text { of } \\
\text { Variance }\end{array}$ & $\begin{array}{c}\text { Cumulati } \\
\text { ve } \%\end{array}$ & Total & $\begin{array}{c}\% \text { of } \\
\text { Varianc } \\
\mathrm{e}\end{array}$ & $\begin{array}{c}\text { Cumulativ } \\
\mathrm{e} \%\end{array}$ \\
\hline 1 & 5.162 & 30.363 & 30.363 & $\mid 5.162$ & 30.363 & 30.363 & 4.486 & 26.388 & 26.388 \\
\hline 2 & 2.580 & 15.176 & 45.539 & 2.580 & 15.176 & 45.539 & 2.120 & 12.473 & 38.861 \\
\hline 3 & 1.805 & 10.615 & 56.154 & 1.805 & 10.615 & 56.154 & 2.065 & 12.150 & 51.011 \\
\hline 4 & 1.118 & 6.574 & 62.728 & 1.118 & 6.574 & 62.728 & 1.779 & 10.467 & 61.478 \\
\hline 5 & 1.034 & 6.080 & 68.808 & 1.034 & 6.080 & 68.808 & 1.246 & 7.330 & 68.808 \\
\hline 6 & .920 & 5.413 & 74.220 & & & & & & \\
\hline 7 & .762 & 4.485 & 78.705 & & & & & & \\
\hline 8 & .668 & 3.928 & 82.633 & & & & & & \\
\hline 9 & .551 & 3.240 & 85.873 & & & & & & \\
\hline 10 & .502 & 2.951 & 88.823 & & & & & & \\
\hline 11 & .443 & 2.607 & 91.431 & & & & & & \\
\hline 12 & .390 & 2.296 & 93.727 & & & & & & \\
\hline 13 & 294 & 1.728 & 95.455 & & & & & & \\
\hline 14 & 269 & 1.580 & 97.035 & & & & & & \\
\hline 15 & 188 & 1.106 & 98.141 & & & & & & \\
\hline 16 & .177 & 1.038 & 99.179 & & & & & & \\
\hline 17 & .140 & .821 & 100.000 & & & & & & \\
\hline
\end{tabular}

Extraction Method: Principal

Component Analysis.

Source: Research data

SPSS analysis has identified 17 factors before the extraction within the data set. The first section of the above table shows the Initial Eigenvalues. Among them, 5 factors which total initial Eigenvalues exceeds one have been extracted in the extraction sums of squared loading section of the above table. Moreover, according to the '\% of variance' column of the extraction sums of squared loadings section, factor 1,2 , 3,4 and 5 together accounts for $68.81 \%$.

Scree Plot

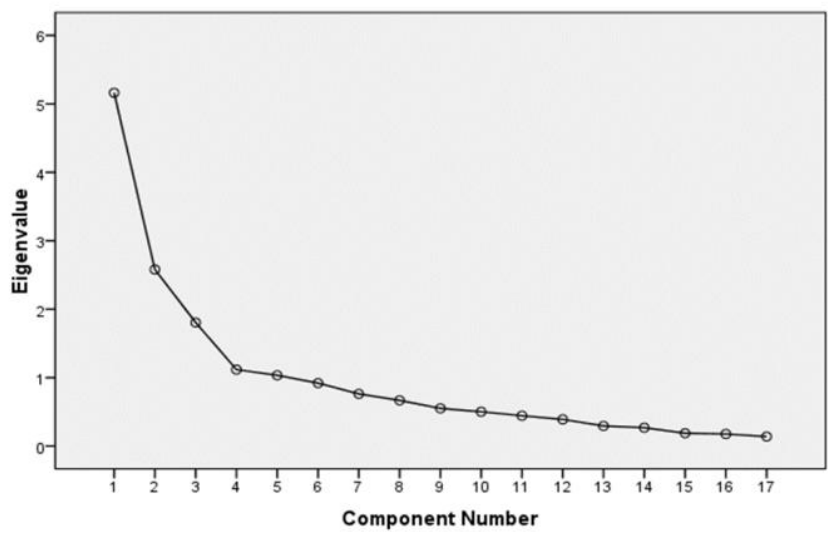

Figure 1.1 Scree plot

Source: Research data

Referring to the above figure, there is a sharp turn (elbow) after 5th Eigen value. Hence the Scree plot denoted that those 5 factors explained highest variability because the graph starts to flatten after factor 5 . The rest of the factors show a little fluctuation and are likely to be insignificant.

Table 1.5 Rotated Component Matrix ${ }^{\mathrm{a}}$

\begin{tabular}{|l|l|l|l|l|l|}
\hline & \multicolumn{5}{l}{ Component } \\
\cline { 2 - 6 } & 1 & 2 & 3 & 4 & 5 \\
\hline Cost of Sourcing & .255 & .076 & .127 & .773 & -.012 \\
Price Competitiveness & .103 & .141 & -.021 & .598 & -.217 \\
Payment term given by the supplier & .014 & .403 & .385 & -.627 & -.099 \\
Technical Capability of the supplier & .631 & .039 & .405 & .021 & -.421 \\
Quality Assessment of the product & .830 & .074 & -.064 & .110 & .100 \\
Commercial support in NPDs/EPDs & .097 & .732 & .192 & .181 & .156 \\
Ethical Contract & .002 & .139 & .912 & -.060 & .113 \\
BCP (Business Continuity Plan of \\
the supplier)
\end{tabular}

Extraction Method: Principal Component Analysis.

Rotation Method: Varimax with Kaiser Normalization

Source: Research data

Table 1.6 shows that how, all questions can be divided in to small groups as per the characteristics they belong. And the results of the factor grouping in factor one is similar in magnitude. Therefore, factors are rotated to gain meaningful factors. Factor rotation has been commenced according to the Varimax with Kaiser Normalization method.

With reference to the rotated component matrix the researcher uses it to mitigate the number of factors to be influenced on strategic souring (Dependent variable). According to the rotated factor loadings, 17 variables can be categorized for extracted five factors based on the highest value of each variable in the table 1.6. The identified variables have been named based on their characteristics as follows.

\section{Component 01: Supplier's Reliability and quality factor}

Factor $01=\mathrm{f}$ \{Ease of Communication with the supplier, Deliveries on-time, Quality Assessment of the product, Risk Factors, Financial health of the supplier, Technical Capability of the supplier, Lead Time

\section{Component 02: Supplier's Business Environment factor}

Factor $02=\mathrm{f}$ \{Commercial support in NPDs/EPDs, Political stability of the supplier, Performance History of the supplier in the respective industry\}

Component 03: Supplier's Sustainability factor

Factor $03=\mathrm{f}\{$ Ethical Contract, BCP (Business Continuity Plan of the supplier)

\section{Component 04: Cost Advantage factor}

Factor $04=\mathrm{f}$ \{Cost of Sourcing, Price Competitiveness $\}$

\section{Component 05: Customer Responsiveness factor}

Factor $05=\mathrm{f}\{$ Response of Customers $\}$

Table 1.6 Component Score Coefficient Matrix 


\begin{tabular}{|c|c|c|c|c|c|}
\hline & \multicolumn{5}{|c|}{ Component } \\
\hline & 1 & 2 & 3 & 4 & 5 \\
\hline Cost of Sourcing & -.008 & -.037 & .078 & .441 & .000 \\
\hline Price Competitiveness & -.025 & .072 & .003 & .329 & -.192 \\
\hline $\begin{array}{l}\text { Payment term given by the } \\
\text { supplier }\end{array}$ & -.019 & .225 & .146 & -.381 & -.203 \\
\hline $\begin{array}{l}\text { Technical Capability of the } \\
\text { supplier }\end{array}$ & .075 & .017 & .196 & -.020 & -.377 \\
\hline $\begin{array}{l}\text { Quality Assessment of the } \\
\text { product }\end{array}$ & .242 & .039 & -.204 & -.004 & .144 \\
\hline $\begin{array}{l}\text { Commercial support in } \\
\text { NPDs/EPDs }\end{array}$ & .000 & .347 & -.031 & .058 & .016 \\
\hline Ethical Contract & -.144 & -.105 & .564 & .015 & -.015 \\
\hline $\begin{array}{l}\mathrm{BCP} \text { (Business Continuity Plan } \\
\text { of the supplier) }\end{array}$ & .022 & -.111 & .369 & .048 & .087 \\
\hline Financial health of the supplier & .120 & -.031 & .140 & .020 & .061 \\
\hline $\begin{array}{l}\text { Organizational Profile of the } \\
\text { supplier }\end{array}$ & .108 & -.186 & .028 & -.154 & -.125 \\
\hline Deliveries on-time & .216 & .015 & -.090 & -.021 & .008 \\
\hline Lead Time & .164 & -.203 & -.066 & -.226 & -.011 \\
\hline $\begin{array}{l}\text { Ease of Communication with } \\
\text { the supplier| }\end{array}$ & .252 & .017 & -.165 & -.032 & .163 \\
\hline Response of Customers & .056 & -.053 & -.015 & -.095 & .674 \\
\hline $\begin{array}{l}\text { Performance History of the } \\
\text { supplier in the respective } \\
\text { industry }\end{array}$ & .042 & .246 & -.047 & -.004 & .222 \\
\hline Risk Factors & .141 & .036 & .033 & .114 & -.102 \\
\hline $\begin{array}{l}\text { Political stability of the } \\
\text { supplier }\end{array}$ & .064 & .480 & -.195 & -.198 & -.280 \\
\hline
\end{tabular}

Extraction Method: Principal Component Analysis.

Source: Research data

\section{Hypothesis Testing}

Hypothesis test for component 01 (Supplier's Reliability and the quality)

$\mathbf{H}_{\mathbf{0}}$ : Strategic sourcing is independent from Supplier's Reliability and the quality

$\mathbf{H}_{1}$ : strategic sourcing is dependent on Supplier's Reliability and the quality

Table 1.7 Chi-Square Test for Supplier's Reliability and quality factor

\begin{tabular}{|l|l|l|l|}
\hline & Value & Df & $\begin{array}{l}\text { Asymp. Sig. } \\
\text { (2-sided) }\end{array}$ \\
\hline $\begin{array}{l}\text { Pearson Chi-Square } \\
\text { Likelihood Ratio }\end{array}$ & $8.207 \mathrm{E} 2^{\mathrm{a}}$ & 120 & .000 \\
Linear-by-Linear & 11.427 & 1 & .001 \\
Association & 303 & 120 & .000 \\
N of Valid Cases & 303 & \\
\hline
\end{tabular}

Source: Research data

According to the test statistics, 2-tailed Pearson Chi-Square value is 0.000 . Since this is less than $0.05, \mathrm{H}_{0}$ is rejected and $\mathrm{H}_{1}$ is accepted. Therefore, it can be indicated that, strategic sourcing is dependent on Supplier's Reliability and quality factor

Hypothesis test for component 02 (Supplier's Business Environment)

$\mathbf{H}_{\mathbf{0}}$ : Strategic sourcing is independent from Supplier's business environment

$\mathbf{H}_{1}$ : Identifying strategic sourcing is dependent on supplier's Business environment

Table 1.8 Chi-Square Test for Supplier's Business
Environmental factor

\begin{tabular}{|l|l|l|l|}
\hline & Value & Df & $\begin{array}{c}\text { Asymp. Sig. } \\
\text { (2-sided) }\end{array}$ \\
\hline $\begin{array}{l}\text { Pearson Chi-Square } \\
\text { Likelihood Ratio }\end{array}$ & $7.745 \mathrm{E} 2^{\mathrm{a}}$ & 150 & .000 \\
Linear-by-Linear & 448.062 & 150 & .000 \\
Association & 46.139 & 1 & .000 \\
N of Valid Cases & 303 & & \\
\hline
\end{tabular}

Source: Research data

According to the test statistics, 2-tailed Pearson Chi-Square value is 0.000 . Since this is less than $0.05, \mathrm{H} 0$ is rejected and $\mathrm{H} 1$ is accepted. Therefore, it can be indicated that strategic sourcing is dependent on Supplier's Business Environment factor.

Hypothesis test for component 03 (Supplier's Sustainability)

$\mathbf{H}_{\mathbf{0}}$ : strategic sourcing is independent from Supplier's Sustainability

$\mathbf{H}_{1}$ : Identifying strategic sourcing is dependent on Supplier's Sustainability

Table 1.9 Chi-Square Test for Supplier's Sustainability factor

\begin{tabular}{|l|l|l|l|}
\hline & Value & df & $\begin{array}{l}\text { Asymp. Sig. } \\
\text { (2-sided) }\end{array}$ \\
\hline Pearson Chi-Square & $3.740 \mathrm{E}^{\mathrm{a}}$ & 60 & .000 \\
Likelihood Ratio & 200.632 & 60 & .000 \\
Linear-by-Linear & 80.907 & 1 & .000 \\
Association & 303 & & \\
N of Valid Cases & 303 & \\
\hline
\end{tabular}

Source: Research data

According to the test statistics, 2-tailed Pearson Chi-Square value is 0.000 . Since this is less than $0.05, \mathrm{H} 0$ is rejected and $\mathrm{H} 1$ is accepted. Therefore, it can be indicated that strategic sourcing is dependent on Supplier's Sustainability factor.

\section{Hypothesis test for component 04 (Cost Advantage)}

$\mathbf{H}_{0}$ : Identifying strategic sourcing is independent from Cost Advantage

$\mathbf{H}_{\mathbf{1}}$ : Identifying strategic sourcing is dependent on Cost Advantage

Table 1.10 Chi-Square Test for Cost Advantage factors.

\begin{tabular}{|l|l|l|l|}
\hline & Value & Df & $\begin{array}{l}\text { Asymp. Sig. } \\
(2 \text {-sided) }\end{array}$ \\
\hline Pearson Chi-Square & $3.453 \mathrm{E} 2^{\mathrm{a}}$ & 75 & .000 \\
Likelihood Ratio & 222.723 & 75 & .000 \\
Linear-by-Linear & 39.531 & 1 & .000 \\
Association & 303 & & \\
N of Valid Cases & 303 & \\
\hline
\end{tabular}

Source: Research data

According to the test statistics, 2-tailed Pearson Chi-Square value is 0.000 . Since this is less than $0.05, \mathrm{H} 0$ is rejected and $\mathrm{H} 1$ is accepted. Therefore, it can be indicated that, strategic 
sourcing is dependent on Cost Advantage factors.

\section{Hypothesis test for factor 05 (Customer Responsiveness factor)}

$\mathbf{H}_{\mathbf{0}}$ : Identifying strategic sourcing is independent from Customer responsiveness factor

$\mathbf{H}_{1}$ : Identifying strategic sourcing is dependent on from Customer responsiveness factor

Table 1.11 Chi-Square Test for Customer Responsiveness factor

\begin{tabular}{|l|l|l|l|}
\hline & Value & df & $\begin{array}{l}\text { Asymp. Sig. } \\
(2 \text {-sided })\end{array}$ \\
\hline Pearson Chi-Square & $1.847 \mathrm{E} 2^{\mathrm{a}}$ & 30 & .000 \\
Likelihood Ratio & 157.602 & 30 & .000 \\
Linear-by-Linear & 1.361 & 1 & .243 \\
Association & 303 & & \\
N of Valid Cases & 303 & \\
\hline
\end{tabular}

Source: Research data

According to the test statistics, 2-tailed Pearson Chi-Square value is 0.000 . Since this is less than $0.05, \mathrm{H} 0$ is rejected and $\mathrm{H} 1$ is accepted. Therefore, it can be indicated that, strategic sourcing is dependent on Responsiveness factor.

\section{Regression Analysis}

The impact of independent variables on the dependent variable (Strategic souring) is analysed through a regression analysis.

Table 1.12 Model Summary of Regression analysis

\begin{tabular}{|l|c|l|l|l|}
\hline Model & $\mathrm{R}$ & R Square & $\begin{array}{c}\text { Adjusted R } \\
\text { Square }\end{array}$ & $\begin{array}{c}\text { Std. Error of } \\
\text { the Estimate }\end{array}$ \\
\hline 1 & $.596^{\mathrm{a}}$ & .355 & .344 & .35469 \\
\hline
\end{tabular}

Source: Research data

Referring to the table 4.18, multiple correlation which is given by $\mathrm{R}$ is 0.596 which indicates that independent variables are having an average association jointly with dependent variable. $\mathrm{R}$ square value is 0.355 which determines that only $35.5 \%$ of strategic sourcing has been covered by the regression model. Even though the value is less than 0.6 , still there is possibility to regression model to be fitted since $\mathrm{R}$ square belongs to sample. Adjusted $\mathrm{R}$ square value is 0.344 which indicates that $34.4 \%$ of strategic sourcing has been covered by the regression model.

Jointly significance of the result is tested using the ANOVA table. Probability of F test statistics should be significant (P $\leq 0.05$ ) to model to be appropriate indicating independent variables jointly influence on strategic sourcing. If the probability of $F$ test statistics is insignificant, the model is not valid.

Table 1.13 ANOVA of Regression analysis

\begin{tabular}{|ll|l|l|l|l|l|}
\hline \multicolumn{1}{|c|}{ Model } & $\begin{array}{l}\text { Sum of } \\
\text { Squares }\end{array}$ & df & $\begin{array}{c}\text { Mean } \\
\text { Square }\end{array}$ & F & Sig. \\
\hline 1 & Regression & 20.534 & 5 & 4.107 & 32.645 & $.000^{\mathrm{a}}$ \\
& Residual & 37.363 & 297 & .126 & & \\
Total & 57.897 & 302 & & & \\
\hline
\end{tabular}

Source: Research data

According to the above table 1.13, the probability of F test statistics is 0.000 indicating that, the model is jointly significant.

\section{Structure of the model:}

Strategic sourcing $=\beta 0+\beta 1$ (Supplier's quality and Reliability) $+\beta 2$ (Supplier's Business Environmental) + $\beta 3$ (Supplier's Sustainability) $+\beta 4($ Cost Advantage) + $\beta 5$ (Responsiveness factors) $+v$

Table 1.14 Coefficients of the components

\begin{tabular}{|c|c|c|c|c|c|c|}
\hline & \multirow[b]{2}{*}{ Model } & \multicolumn{2}{|c|}{$\begin{array}{l}\text { Unstandardized } \\
\text { Coefficients }\end{array}$} & \multirow{2}{*}{$\begin{array}{c}\text { Standardized } \\
\text { Coefficients }\end{array}$} & \multirow[b]{2}{*}{$t$} & \multirow[b]{2}{*}{ Sig. } \\
\hline & & B & Std. Error & & & \\
\hline \multirow[t]{6}{*}{1} & (Constant) & .162 & .502 & & .323 & .747 \\
\hline & Component_1 & .191 & .095 & .107 & 2.008 & .046 \\
\hline & Component_2 & .186 & .047 & .211 & 3.973 & .000 \\
\hline & Component_3 & .533 & .065 & .469 & 8.131 & .000 \\
\hline & Component_4 & .261 & .085 & .160 & 3.089 & .002 \\
\hline & Component_5 & -.098 & .041 & -.120 & -2.403 & .017 \\
\hline
\end{tabular}

Source: Research data

According to the regression result, probability of Supplier's Business Environmental factor, Supplier's Sustainability factor and Cost Advantage factor are highly significant as probability values are less than 0.05 while Supplier's Reliability factors and Responsiveness factors are individually insignificant since probability values are more than 0.05. This means that they do not individually influence on strategic sourcing. But jointly influence.

When considering the direction of the coefficients of components, coefficient of Customer Responsiveness factor shows an inverse relationship with strategic sourcing while Suppliers reliability and the quality factor, Supplier's Business Environmental factor, Supplier's Sustainability factor and Cost Advantage factors positively influence on strategic sourcing.

According to the weightage of the coefficients, the regression model can be constructed as follows.

\section{Strategic Sourcing $=0.162+0.533$ (Supplier's Sustainability) $+0.261($ Cost Advantage $)+$ 0.191(Supplier's Reliability) 0.186(Supplier's Environmental) - 0.098(Responsiveness factors) + vi}

\section{CONCLUSION}

Based on the analysis of demographic factors, around $87 \%$ of the total respondents were from multinationals because four out of five companies selected for the study are multinationals while around $13 \%$ of the respondents are from local companies in the industry. Practical experience along with strong theoretical knowledge need to make personnel an all-rounder in this functional area of study. $63 \%$ majority of the respondents who have been a part of this survey are having bachelor's degree and second largest portion has taken by respondents who are having master's degree as their educational qualification. Descriptive statistics have been used to understand the nature of data.

As the first objective of this research is to determine the factors affecting on the strategic sourcing in FMCG 
industry in Sri Lanka. Five factors were extracted from the results of Rotated component matrix in factor analysis. They are Supplier's Reliability and the quality, Supplier's Business Environment, Supplier's Sustainability, Cost Advantage and Customer Responsiveness. According to the regression analysis, $35.5 \%$ of strategic sourcing has been covered by the regression model. Based on the coefficients obtained from the analysis, Regression model can be expressed as follows.

Strategic sourcing $=0.162+0.191$ (Supplier's Reliability and the quality) +0.186 (Supplier's Business Environment) 0.533(Supplier's Sustainability) + 0.261(Cost Advantage) 0.098 (Customer Responsiveness) $+v i$

\section{RECOMMENDATION}

Based on the factors summarized in the factor analysis, it is recommended to policy makers of the companies to observe this concept wisely to identify where the policies should be inserted in the FMCG market in Sri Lanka.

Also, it can be recommended to consider the most important factors such as supplier's reliability and the quality, supplier's sustainability factors for decision making on strategic sourcing rather than being cost focus in traditional sourcing. Under the concept of Suppliers reliability and the quality, it is very important to focus more on Communication with the supplier, Deliveries on-time, Quality Assessment of the product, Risk Factors, Financial health of the supplier, Technical Capability of the supplier and Lead Time and also supplier' sustainability is the Ethical Contract and BCP (Business Continuity Plan) of the supplier. Focusing more on these determinants definitely will push the companies in FMCG industry towards success in current turbulent environment as long-term goals should be met without having any unnecessary confusion.

As the ways to move towards strategic souring, Strategic supplier Relationship Management, Best-value Spend and Category Management Strategy, Weighted Average Supplier Scoring Strategy, Collaborative Best-value Sourcing Strategy, Outsourcing and Dual sourcing can be recommended as majority of the respondents have selected the answer to a "Great extent".

\section{References}

1. Adegoke, O., \& Arnold, M. (2009). Criteria for sourcing from developing countries. Emerald Group Publishing Limited, Vol. 2, No. 2., pp. 145164.

2. Adipola, D. (2017). Factors affecting waste generation and ways of optimize in fast moving goods industry in Sri Lanka. Cinec Journal.

3. Amy, Z. (2003). Global Sourcing; process and design for efficient management. Supply Chain Management: An international journal volume 8 , pp 367-379.

4. Benn, L. (2009). Strategic purchasing, supply management practices and buyer performance improvement: an empirical study of UK manufacturing organisations. International Journal of Production Research, 2649-2667.
5. Bolisani, E. and Scarso, E. (1996), "International manufacturing strategies: Experiences from the apparel industry", International Journal of Operations and Production Management, Vol. 16, No. 11, pp. 71-84.

6. Carr, A., \& Pearson, J. (2002). The Impact of Purchasing and Supplier Involvement on Strategic Purchasing and Its Impact on Firm's Performance. International Journal of Operations \& Production Management.

7. Carr, A., \& Smeltzer, R. (1999). The relationship of strategic purchasing to supply chain management. European Journal of Purchasing and Supply Management, 5 (1), 43-51.

8. Christopher, M. and Towill, D.R. (2002), "Supply chain migration from lean and functional to agile and customised", Supply Chain Management: An International Journal, Vol. 5, No. 4, pp. 206-215.

9. Damodar GUJARATI. Basic Econometrics. McGraw-Hill, 1978. Brazilian Review of Econometrics, 7(1), 83. doi: 10.12660/bre v7n11987.3105

10. David, \& Fred, R. (2001). Strategic management: Concepts and cases. New Jersey: Pearson, 114-153.

11. Harps, L. (2000). The Haves and the Have Nots; Supply Chain Practices for the New Millenium. Inbound Logistics Journal, 75-114.

12. Jin, B. (2004), “Achieving an optimal global versus domestic sourcing balance under demand uncertainty", International Journal of Operations and Production Management, Vol. 24, No. 11/12, pp. 1292-1305.

13. Perry, M. and Sohal, A.S. (2000), "Quick response practices and technologies in developing supply chains: A case study", International Journal of Physical Distribution and Logistics Management, Vol. 30, No. 7/8, pp. 627-639.

14. Ruth, M. (2012). Factors Affecting the Selection of Optimal Suppliers in Procurement Management. International Journal of Humanities and Social Science, Vol. 2 No. 14.

15. Stanley, K. (2012). Factors affecting the selection of optimal suppliers in procurement management. International Journal of Humanities and Social Science.

16. Su, J. (2013). Strategic sourcing in the textile and apparel industry. Emerald Group Publishing Limited; Vol. 113 Issue: 1, pp.23-38.

17. SUPPLY MANAGEMENT (pp. 5-13). Bangkok, Thailand: SPRINGER.

18. The Use of Cronbach's Alpha When Developing and Reporting Research Instruments in Science Education. Research In Science Education, 48(6), 1273-1296. doi: 10.1007/s11165-016-9602-2 